\title{
Reduced uptake of apoptotic cells by macrophages in systemic lupus erythematosus: correlates with decreased serum levels of complement
}

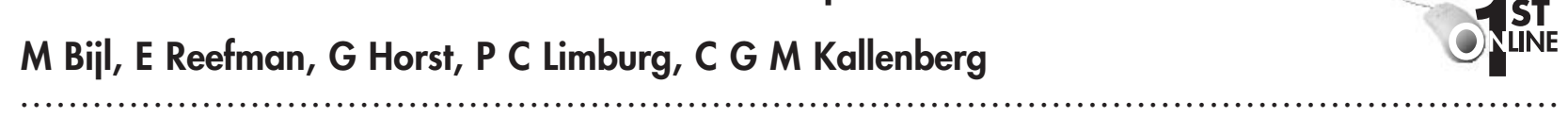

Ann Rheum Dis 2006;65:57-63. doi: 10.1136/ard.2005.035733

See end of article for authors' affiliations

.....................

Correspondence to: $\operatorname{Dr} M$ Biil, Department of Internal Medicine, Division of Clinical Immunology, University Hospital, PO Box 30.001, 9700 RB Groningen, The Netherlands; m.bii|@int.azg.nl

Accepted 19 May 2005 Published Online First 26 May 2005

\begin{abstract}
Background: Defects in phagocytosis of apoptotic cells have a role in the pathogenesis of autoimmune diseases. Decrease of phagocytosis of apoptotic cells occurs in systemic lupus erythematosus (SLE). Factors underlying this decrease are, presently, unknown.

Objective: To analyse the expression of relevant membrane receptors of monocyte derived macrophages (MDM) from patients with SLE and assess their ability to phagocytose apoptotic cells in comparison with MDM from healthy controls. Additionally, to compare phagocytosis in the presence of SLE sera with that in normal human serum (NHS).

Methods: Human peripheral blood monocytes were isolated from patients and controls, and cultured for 7 days to obtain MDM. Membrane expression of CD14, CD18, CD36, and CD51/61 was measured. MDM were incubated with apoptotic Jurkat cells in the presence of NHS or serum from patients with active or inactive disease.

Results: No differences in phagocytosis capacity were found between MDM from patients and controls. Membrane expression of the respective receptors was comparable in patients and controls. However, when MDM from controls were incubated with apoptotic cells in patient serum, phagocytosis was significantly decreased in comparison with incubation in NHS. This effect depended on the patients' disease activity and could be reversed by addition of NHS. Reduced uptake of apoptotic cells was associated with decreased levels of complement $\mathrm{Clq}, \mathrm{C} 4$, and C3, but not with levels of complement factor B.

Conclusions: Reduced uptake of apoptotic cells by MDM from patients with SLE is not an intrinsic defect but is serum dependent and associated with decreased levels of $\mathrm{Clq}, \mathrm{C} 4$, and C3.
\end{abstract}

complement components, phospholipase $\mathrm{A} 2$, and the pentraxins $\mathrm{C}$ reactive protein $(\mathrm{CRP})$, serum amyloid $\mathrm{P}$, and pentraxin-3 bind to apoptotic cells and mediate their uptake by macrophages. ${ }^{13-17}$ Their relevance is demonstrated by a defect in the phagocytic uptake of apoptotic syngeneic thymocytes in C4 deficient mice. ${ }^{3}$

Up till now, it has not been clear whether the defect found in patients with SLE is intrinsic to their macrophages, or acquired owing to serum derived factors, such as a decline of complement levels during active disease. We conducted this study to investigate whether an intrinsic defect in phagocytosis of apoptotic cells is present in patients with SLE. We analysed the expression of membrane receptors on macrophages involved in the uptake of apoptotic cells and studied their phagocytic capacity when incubated in normal serum. In addition, we analysed the differential effects of SLE sera on this process in order to approach the in vivo situation.

\section{PATIENTS AND METHODS}

\section{Patients and controls}

Patients eligible for this study fulfilled at least four American College of Rheumatology criteria for SLE. ${ }^{18}$ For monocyte isolation 16 consecutive patients with inactive disease were selected. Table 1 shows the patient characteristics. Simultaneously, monocytes were collected from 16 healthy controls matched for age and sex. To test the influence of

Abbreviations: CRP, $\mathrm{C}$ reactive protein; $\mathrm{MDM}$, monocyte derived macrophages; MFI, mean fluorescence intensity; NHS, normal human serum; PBMC, peripheral blood mononuclear cells; SLE, systemic lupus erythematosus kinase c-mer), the vitronectin receptor (CD51/CD61), CD44, and the phosphatidylserine receptor. ${ }^{9-12}$ Next to $\mathrm{Clq}$, other 


\begin{tabular}{ll} 
Table 1 Characteristics of the 16 patients with \\
SLE from whom monocytes were isolated during \\
inactive disease \\
\hline $\begin{array}{ll} \\
\text { Age (years), mean (range) }\end{array}$ & $45.7(26-77)$ \\
Male/female & $2 / 14$ \\
Disease duration (years), mean (range) & $14.2(4-44)$ \\
SLEDAl & $2.4(0.4)$ \\
CRP (mg/l) & $2.2(1.1)$ \\
Anti-dsDNA (Farr, IU/ml) & $51.9(21.6)$ \\
Complement C3 (g/l) & $0.87(0.05)$ \\
Complement C4 (g/l) & $0.12(0.01)$ \\
Cumulative ACR criteria, No (\%) & $5(31)$ \\
Malar rash & $3(19)$ \\
Discoid rash & $8(50)$ \\
Photosensitivity & $4(25)$ \\
Oral ulcers & $9(56)$ \\
Arthritis & $8(50)$ \\
Serositis & $8(50)$ \\
Nephritis & $2(13)$ \\
Central nervous system & $12(75)$ \\
Haematological & $14(88)$ \\
Anti-dsDNA antibodies & $2(13)$ \\
Anti-Smith antibodies & $16(100)$ \\
Antinuclear antibodies & \\
\hline Results are given as mean (SEM), unless depicted otherwise. \\
EE cell phenomenon and/or false positive syphilis test are not \\
included in the table because neither was routinely analysed \\
in our centre.
\end{tabular}

serum in phagocytosis studies, paired serum samples were used, obtained from another 20 patients at the moment of active and inactive disease, respectively. Patients with active disease had to fulfil criteria as previously described. ${ }^{19}$ Inactive disease was defined as the persistent absence of clinical disease activity for at least 4 months while patients were receiving a constant dose of immune modulating drugs or none at all. Table 2 gives the characteristics of these patients. For each participating patient a SLEDAI score was recorded. ${ }^{20}$

\section{Complement levels}

Complement C3 and C4 levels were detected by radioimmunodiffusion according to the manufacturer's instruction (Dade Behring, Marburg, Germany). Complement Clq and factor B were measured by nephelometry.

\section{Macrophage culture}

Peripheral blood mononuclear cells (PBMC) were isolated as described previously. ${ }^{21}$ PBMC from patients and controls were isolated and cultured pair wise to avoid differences in conditions.

\section{Expression of membrane receptors}

Monocyte surface marker analysis was performed by incubating $200 \mu \mathrm{l}$ whole blood with $10 \mu \mathrm{l}$ labelled monoclonal antibody (table 3) for 15 minutes at room temperature. Subsequently, $3 \mathrm{ml}$ 1:10 FACS lysing solution was added for 10 minutes at room temperature, samples were washed with phosphate buffered saline/heparin and taken up in $150 \mathrm{ml}$ phosphate buffered saline/heparin. The same analysis was performed immediately after isolation of the mononuclear cell fraction and after 7 days of culture and measured on a Coulter Epics-Elite (Coulter Electronics, Mijdrecht, The Netherlands).

The level of expression of membrane markers was given as the mean fluorescence intensity (MFI), corrected for nonspecific binding using an irrelevant antibody. Human umbilical vein endothelial cells were used as positive control for CD51/61 and monocyte derived dendritic cells for CD83 staining. Monocyte derived dendritic cells were obtained by 7 days of culture in RPMI, supplemented with granulocyte monocyte-colony stimulating factor $(800 \mathrm{IU} / \mathrm{ml})$, interleukin
Table 2 Characteristics of the 20 patients with SLE from whom serum was obtained during inactive and active disease

\begin{tabular}{llll}
\hline Characteristics & Inactive & Active & p Value \\
\hline SLEDAl & $2.2(0.4)$ & $11.8(1.2)$ & $<0.0001$ \\
CRP (mg/l) & $6.5(2.3)$ & $38.3(13.4)$ & 0.0194 \\
Anti-dsDNA (IU/ml) & $28.8(8.4)$ & $201.4(67.8)$ & 0.0007 \\
Complement C3 (g/l)* & $1.20(0.08)$ & $0.79(0.06)$ & 0.0003 \\
Complement C4 (g/l)* & $0.19(0.02)$ & $0.11(0.01)$ & 0.0005 \\
Complement Clq (g/l)* & $0.14(0.01)$ & $0.08(0.01)$ & 0.0007 \\
Complement factor B (g/l)* & $0.33(0.02)$ & $0.29(0.03)$ & 0.1418 \\
\hline Results are given as mean (SEM). & & \\
p Values were calculated using Wilcoxon's signed rank test. \\
*Normal C3 and C4 values are 0.77-1.84 and 0.16-0.40 g/l, \\
respectively. Normal values of Clq and factor B are 0.10-0.25 and \\
O.19-0.40 g/l, respectively.
\end{tabular}

$4(100 \mathrm{IU} / \mathrm{ml})$, and $10 \%$ fetal calf serum, and subsequent simulation with lipopolysaccharide $(1 \mu \mathrm{g} / \mathrm{ml})$ for 2 days.

\section{Induction and detection of apoptosis}

Apoptosis in Jurkat cells was induced as described previously. ${ }^{21}$ After 4 hours 54.0 (5.1)\% (mean (SEM) of three experiments) of Jurkat cells were positive for annexin $\mathrm{V}$ and negative for propidium iodide, while 5.3 (1.5)\% were positive for both markers.

\section{Phagocytosis assay}

A phagocytosis assay was performed as described previously. ${ }^{21}$ In short, irradiated Jurkat cells $\left(2 \times 10^{6}\right.$ cells/well $)$ and macrophages were incubated for 30 minutes at $37^{\circ} \mathrm{C}$, in the presence of $30 \%$ pooled normal human serum (NHS) of healthy subjects. Subsequently, cover slips were washed gently to remove non-bound cells. Four serum samples from a patient with active SLE with resulting low phagocytic capacity were reconstituted using a mix of $15 \%$ active serum and 15\% NHS and compared with 30\% active SLE serum alone, or $15 \%$ active serum and 30\% NHS.

\section{Staining procedure and scoring of macrophage density and phagocytosis}

Staining procedures were performed as described previously. ${ }^{21}$ Preparations were scored by two independent observers at $\times 400$ magnification using light microscopy. The density of macrophages was determined by averaging the number of macrophages in three microscopic fields. Phagocytosis was expressed as a phagocytosis index (number of Jurkat cells internalised by 100 macrophages). All experiments were performed in duplicate.

\section{Statistics}

Levels of statistical significance were calculated using GraphPad Prism (version 3.0; GraphPad software). Comparison between groups was performed using MannWhitney U test, Wilcoxon's signed rank test or one way analysis of variance for selected pairs of columns, with Bonferroni's correction for multiple comparisons as appropriate. Correlations were calculated using Spearman's rank correlation test.

\section{RESULTS}

\section{Phagocytosis of apoptotic cells}

For phagocytosis experiments monocytes were isolated from 16 patients with SLE, with inactive disease, and 16 healthy age and sex matched controls, and differentiated into macrophages (MDM). To detect intrinsic defects in the capacity to internalise apoptotic cells, MDM from patients with inactive disease and controls were incubated with 
Table 3 Membrane markers used

\begin{tabular}{|c|c|c|c|c|}
\hline Marker & Label & Cellular distribution & $\begin{array}{l}\text { Monoclonal } \\
\text { antibody }\end{array}$ & Source \\
\hline CD14 & $\mathrm{PE}$ & Monocytes/macrophages/granulocytes (weak) & $\lg G 2 a$ & IQP \\
\hline CD18 & FITC & All types of leucocytes & $\lg G 1$ & Imm. Tech \\
\hline CD36 & FITC & Monocytes/macrophages/platelets/erythrocyte precursors & $\lg G 1$ & IQP \\
\hline CD51/61 & FITC & Endothelium/platelets/monocytes/macrophages & $\lg G 1$ & $\mathrm{BD}$ \\
\hline CD83 & FITC & Dendritic cells & $\lg G 1$ & $\mathrm{BD}$ \\
\hline HLA-DR & PE & Antigen presenting cells & $\lg G 2 a$ & $\mathrm{BD}$ \\
\hline
\end{tabular}

apoptotic Jurkat cells in the presence of NHS. No differences in phagocytic capacity could be demonstrated between patients and controls (fig lA). As it has been reported that the density of MDM can influence their capacity to internalise apoptotic cells, the density of MDM after culture was determined. No differences between patients and controls could be detected in the density of macrophages (fig 1B).

\section{Expression of membrane receptors}

To analyse whether the expression of membrane receptors, relevant for binding and subsequent internalisation of apoptotic cells, differed between patients and controls membrane expression of CD14, CD18, CD36, and the vitronectin receptor $(\mathrm{CD} 51 / 61)$ was measured on mononuclear cells by flow cytometry. For this purpose, some of the MDM from eight patients and eight controls, as prepared for the phagocytosis experiments, were used. Membrane expression was measured in whole blood and after isolation of mononuclear cells in order to analyse the influence of isolation. No differences were found in the percentage of CD14, CD18, CD36, or CD51/61 positive cells between patients and controls (data not shown). Also, the level of membrane expression, indicated as the MFI, was comparable between patients and controls at any time point (table 4). However, isolation of the mononuclear cell fraction resulted in a significant decrease in CD14 expression. After 7 days of culture, a further reduction in CDI4 expression, and a significant decrease in the expression of CD18 and CD36 could be demonstrated on MDM both from patients and controls (table 4). CD83 expression remained negative, indicating that no differentiation into dendritic cells had occurred during the culture period.

\section{Effect of serum}

To test whether constituents present in patients' and control serum influence the phagocytic capacity of MDM, phagocytosis experiments were performed using different serum samples. Incubation of control MDM with apoptotic Jurkat cells was now performed in the presence of serum derived from patients with active disease $(n=20)$, from the same patients with inactive disease $(n=20)$ (table 2$)$, and with NHS $(n=20)$, in decreasing concentrations. The phagocytic capacity of control MDM was dependent on serum concentration as demonstrated by the positive relation between serum concentration and phagocytosis index (fig 2). Furthermore, compared with NHS, a significant decrease in phagocytosis index was observed when 30,20 , or $10 \%$ serum from patients with active disease was added during incubation of apoptotic Jurkat cells with MDM from healthy controls $(\mathrm{p}<0.001, \mathrm{p}<0.05$, and $\mathrm{p}<0.01$, respectively $)$. Addition of NHS was able to restore phagocytosis when mixed 1:1 with serum of patients with active SLE (fig 3). Except for complement factor B, all complement levels were decreased during active disease (table 2). We analysed whether the decrease of complement levels was related to the decrease in phagocytosis index as found in the presence of serum from patients with active lupus. A significant correlation could be demonstrated between serum levels of complement Clq, C4, and C3 and the phagocytosis index (fig 4). No correlations were found between the phagocytosis index and complement factor B $(p=0.99)$, levels of CRP $(p=0.82)$, and levels of anti-dsDNA antibodies $(p=0.85)$ or the presence of antiphospholipid antibodies.

\section{DISCUSSION}

This study demonstrates that the intrinsic capacity of MDM from patients with SLE to internalise apoptotic cells is unaltered compared with controls. In addition, the expression of membrane receptors on monocytes as well as on MDM relevant for the uptake of apoptotic cells did not differ between patients and controls. However, when phagocytosis experiments were performed with MDM from healthy controls incubated with sera derived from patients with active SLE, a significant decrease in the phagocytosis of apoptotic cells was seen. This decrease in phagocytosis could
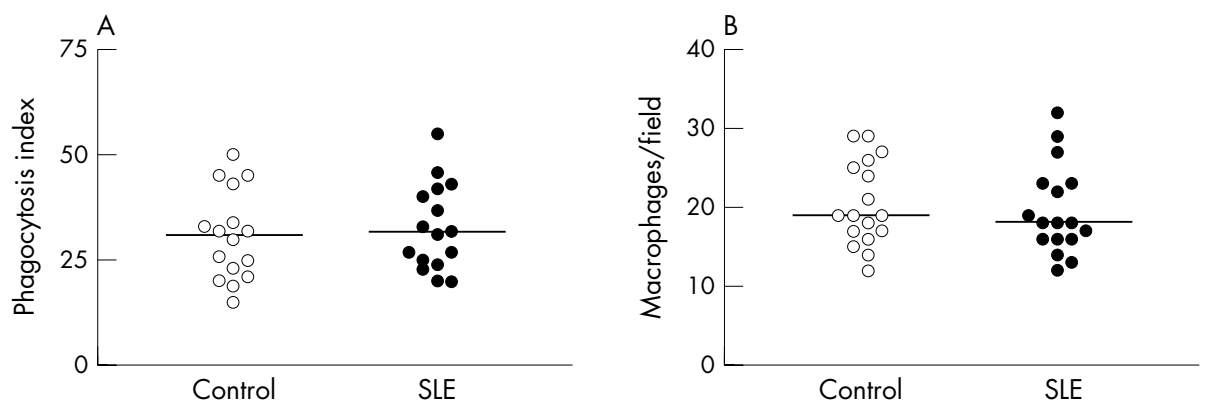

Figure 1 Phagocytosis of apoptotic Jurkat cells by monocyte derived macrophages (MDM) and density of MDM on cover slips from 16 healthy controls and 16 patients with SLE with inactive disease. (A) Phagocytosis occurred in the presence of $30 \%$ pooled serum of normal healthy subjects. The phagocytosis index was calculated as the number of apoptotic Jurkat cells internalised by 100 MDM. (B) Density of MDM was scored after phagocytosis and depicted as the number of MDM per microscopic field. Horizontal bars denote the median. 
Table 4 Membrane expression of several receptors measured on monocytes before and after isolation and on monocyte derived macrophages after 7 days of culture

\begin{tabular}{|c|c|c|c|c|c|c|}
\hline \multirow[b]{2}{*}{ Marker } & \multicolumn{2}{|l|}{ Whole blood } & \multicolumn{2}{|l|}{ After isolation } & \multicolumn{2}{|c|}{ After 7 days culture } \\
\hline & $\begin{array}{l}\text { Controls } \\
(n=8)\end{array}$ & $\begin{array}{l}\text { SLE } \\
(n=8)\end{array}$ & $\begin{array}{l}\text { Controls } \\
(n=8)\end{array}$ & $\begin{array}{l}\text { SLE } \\
(n=8)\end{array}$ & $\begin{array}{l}\text { Controls } \\
(n=8)\end{array}$ & $\begin{array}{l}\text { SLE } \\
(n=8)\end{array}$ \\
\hline CD14 & 1045.0 (97.9) & 816.0 (106.2) & $709.2(115.5)^{*}$ & $544.9(82.6)^{* *}$ & $32.5(14.0) \dagger$ & $62.6(17.4)+\dagger$ \\
\hline CD18 & $147.4(16.6)$ & $134.4(13.4)$ & $253.0(62.6)$ & 223.7 (47.4) & $52.3(10.5)+\dagger$ & 61.8 (13.9)t† \\
\hline CD36 & $395.6(52.8)$ & $384.0(41.0)$ & $419.9(71.9)$ & $416.4(50.7)$ & $39.9(7.2) \dagger$ & $70.1(13.7)+\dagger$ \\
\hline CD51/61 & $1.80(0.56)$ & $2.33(0.78)$ & $8.3(6.6)$ & $5.3(3.0)$ & $2.9(0.84)$ & $4.8(3.2)$ \\
\hline CD83 & $2.22(0.49)$ & $1.78(0.46)$ & $3.9(2.3)$ & $3.0(1.2)$ & $1.3(0.17)$ & $3.3(1.4)$ \\
\hline HLA-DR & $328.1(39.4)$ & $547.2(220.8)$ & $255.8(68.9)$ & $209.7(67.2)$ & $214.0(634)$ & $243.1(44.3)$ \\
\hline
\end{tabular}

Results are given as mean (SEM) and represent the MFI of the respective markers, corrected for non-specific binding of an irrelevant antibody and the conjugate. No differences in membrane expression could be demonstrated between patients and controls (using the Mann-Whitney $U$ test).

Differences between results on whole blood and after isolation are depicted as ${ }^{*} p<0.05$ and ${ }^{* *} p<0.01$; differences between results directly after isolation and after 7 days of culture are depicted as $t p<0.05$ and $+\uparrow p<0.01$ as analysed by Wilcoxon signed rank pairs test.

be restored by the addition of NHS to serum from patients with active disease. The lowered capacity to clear apoptotic cells was associated with decreased levels of complement factors C1q, C4, and C3 which confirms, in part, the results of others. ${ }^{22}$

In recent years the role of apoptotic cells in the development of autoimmunity has been highlighted. ${ }^{23}{ }^{24}$ Apoptotic cells display intracellular autoantigens on their cell membrane. ${ }^{25}$ These autoantigens expressed on membranes might be altered through post-translational modification processes. $^{26}{ }^{27}$ It has been suggested that persistent exposure to these cells can break tolerance. ${ }^{28} 29$ A diminished capacity to phagocytose apoptotic cells is supposed to be one of the major mechanisms that may underlie this persistent exposure.

Membrane receptors on phagocytes and opsonising serum constituents have a role in the uptake of apoptotic cells. In patients with SLE, membrane expression of these relevant receptors on monocytes/macrophages has been examined in several studies. CD44 expression has been reported to be reduced on monocytes of patients with SLE. ${ }^{30}$ One study showed a reduction in the expression of CDI4 on monocytes of patients with SLE after 7 days of culture. ${ }^{8}$ In contrast, Steinbach et al found a reduction in CD14 expression on freshly isolated monocytes of patients with SLE. ${ }^{31}$ In our study we could not demonstrate any difference between healthy controls and patients with SLE in membrane expression of CD14, CD18, CD36, or CD51/61 immediately after isolation, nor after differentiation into MDM. However, we did show that isolation of PBMC as well as culture of MDM significantly influence membrane expression of several receptors. Differences in methodology might, therefore, account for the discrepancies in the results found between studies.
Together with the absence of changes in receptor expression on MDM from patients with SLE, the normal phagocytic capacity of MDM from patients with SLE found in the current study strongly suggests that no intrinsic abnormalities in their MDM are present. Also, experiments in lupus prone mouse strains suggest that the capacity of macrophages to internalise apoptotic cells is normal. ${ }^{32}$ Licht et al investigated the efficacy of phagocytosis of apoptotic thymocytes in vitro in the presence of fetal calf serum by resident peritoneal macrophages in control and MRL/+ and MRL/lpr lupus prone mouse strains. ${ }^{33}$ They did not detect any changes in efficacy between these mouse strains. However, a decrease in phagocytosis was detected in lupus prone mouse strains in the presence of autologous serum. ${ }^{32}$ The decreased in vivo phagocytosis in MRL/Mp and NZB/W lupus prone mouse strains found by others might, therefore, be a consequence of differences in levels of serum factors in these mice. ${ }^{34}$

The study by Herrmann et al showed that clearance of apoptotic cells by MDM from patients with SLE is reduced in the presence of normal serum. ${ }^{8}$ This might be explained by differences in methodology. Firstly, monocytes in this study were collected from patients with inactive disease as well as active disease. Furthermore, a previous report has shown that incubation of rat bone marrow derived macrophages with apoptotic neutrophils for 30 minutes reduces the uptake of apoptotic neutrophils at a rechallenge after 48 hours by $50 \%$ compared with previously unchallenged bone marrow derived macrophages. ${ }^{35}$ In patients with lupus an increased level of circulating apoptotic neutrophils can be found in the peripheral blood. This level correlates positively with disease activity. ${ }^{36}$ Phagocytosis of these cells by macrophages might therefore negatively influence the ability of these

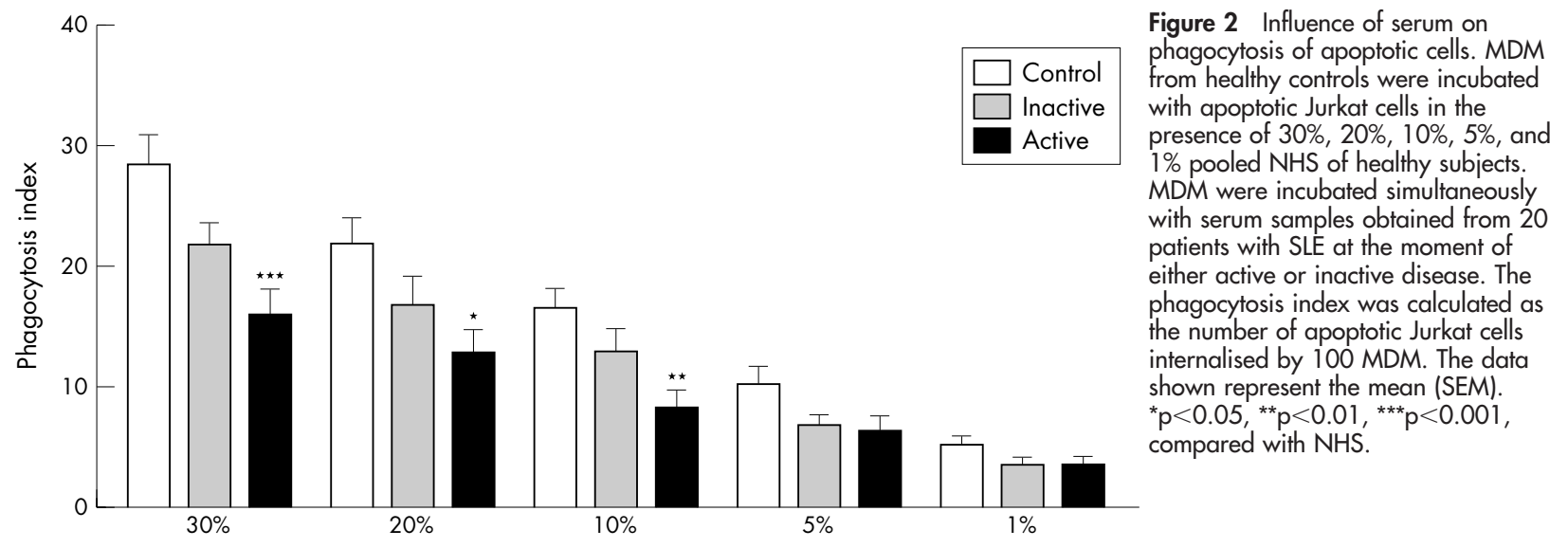

Figure 2 Influence of serum on phagocytosis of apoptotic cells. MDM from healthy controls were incubated with apoptotic Jurkat cells in the presence of $30 \%, 20 \%, 10 \%, 5 \%$, and $1 \%$ pooled NHS of healthy subjects. MDM were incubated simultaneously with serum samples obtained from 20 patients with SLE at the moment of either active or inactive disease. The phagocytosis index was calculated as the number of apoptotic Jurkat cells shown represent the mean (SEM). ${ }^{*} p<0.05,{ }^{* *} p<0.01,{ }^{* * *} p<0.001$, 

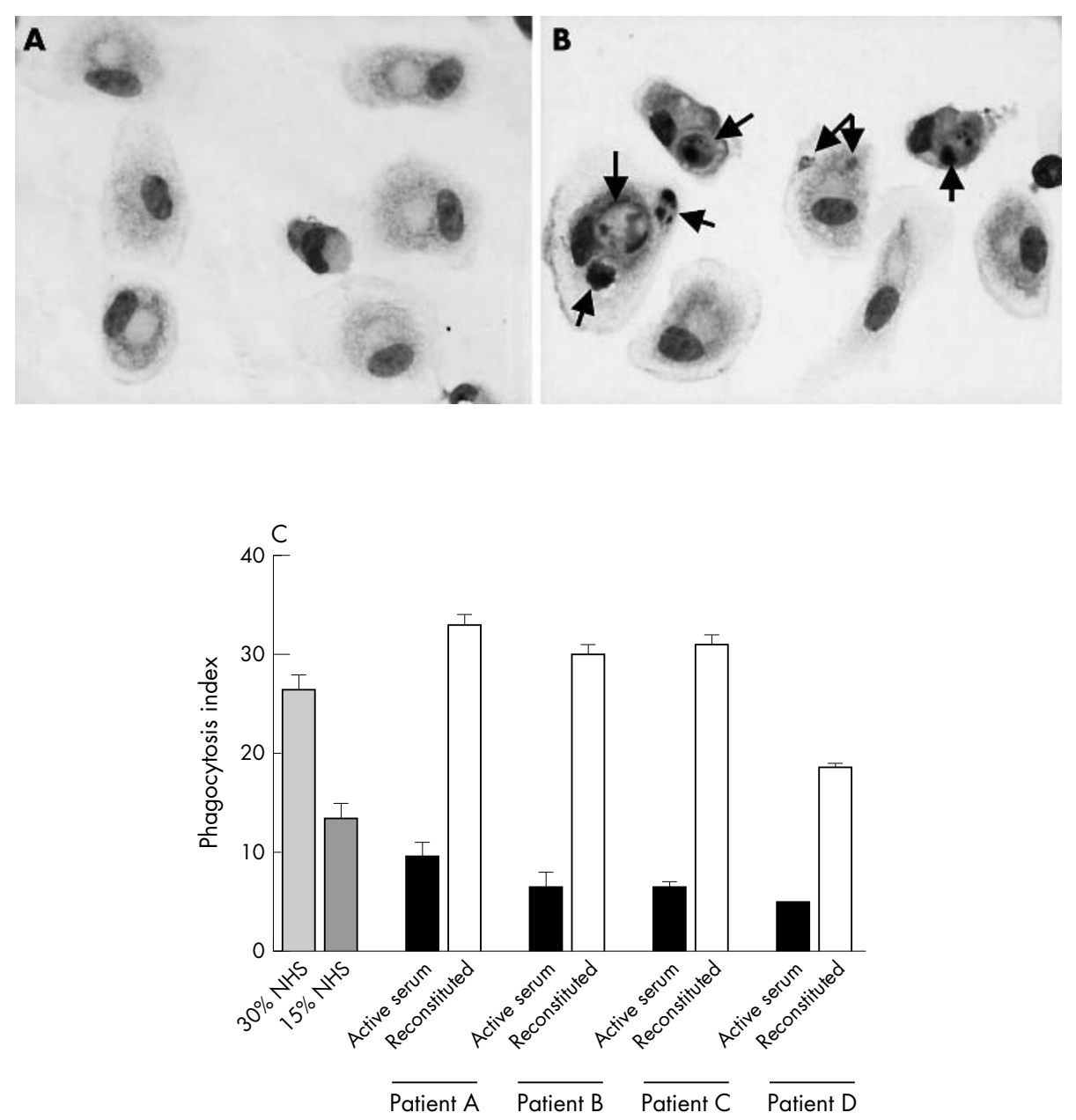

Figure 3 Reconstitution of active patient serum restored phagocytic activity. Phagocytosis of apoptotic Jurkat cells by MDM from healthy controls was performed in $30 \%$ or $15 \%$ pooled NHS, in $30 \%$ serum from patients with active disease (active serum), or in a mixture of $15 \%$ serum from patients with active disease and 15\% NHS (reconstituted) using four patients. (A) MDM after incubation with apoptotic Jurkat cells in $30 \%$ serum from patients with active disease. (B) MDM seen after reconstitution of these serum samples from patients with active disease. Black arrows indicate phagocytosed cells. (C) Measurement of phagocytosis in four patients without and with 1:1 reconstitution with NHS. Experiments were performed in duplicate and data represent the mean (SEM).

macrophages to ingest other apoptotic cells. This might explain the decreased phagocytosis by MDM of patients with SLE found by Herrmann et al, who incubated apoptotic cells with MDM for long periods of time. ${ }^{8}$ Finally, the ability to internalise apoptotic cells has also been shown to be dependent on contacts between macrophages themselves, called the community effect. ${ }^{37}$ Shoshan et al demonstrated that during maturation of monocytes from patients with SLE into macrophages, accelerated apoptosis occurred, which resulted in a lower density of macrophages and a reduced ability to internalise apoptotic cells. Phagocytosis was restored to control levels by restoring cell density. ${ }^{37}$ Cell densities were not taken into account in the study of Herrmann et al. Differences in cell density may be another explanation for the discrepancies found between our study and that of Herrmann et al. In the present study, effects of cell density could be ignored as macrophage density did not differ between patients and controls.

The role of complement factors in the uptake of apoptotic cells has clearly been demonstrated. ${ }^{38}$ The presence of the classical pathway complement proteins seems essential for phagocytosis of apoptotic cells. In mice, disruption of the Clq gene results in spontaneous autoimmunity. ${ }^{3}$ Also, C4 deficiency causes spontaneous, lupus-like autoimmunity, with glomerulonephritis and glomerular deposition of immune complexes. ${ }^{38}$ Recently, it was shown using single and double knockout C3(null)C4(null) lpr (Fas deficient) mouse models, that the absence of $\mathrm{C} 4$, and not the presence of C3, is critical in the development of SLE. ${ }^{39}$ Thus, next to Clq, complement C4 provides an important protective role against the development of SLE. In accordance with these data we demonstrate that the uptake of apoptotic cells through MDM is reduced in association with reduced levels of Clq as well as C4 in sera used in the phagocytosis experiments.

In a recent study by our group no correlations could be detected between serum complement levels and phagocytic capacity using serum samples from patients with inactive SLE. ${ }^{40}$ Although a moderate decrease in complement factors was detected in these patients with inactive SLE, this might not be sufficient to effect phagocytosis of apoptotic cells. In our current study only serum samples from patients with SLE in an active state of the disease have significantly decreased phagocytic capacity, which correlated with extremely low complement levels.

Furthermore, reconstituting complement deficient sera from patients with active lupus with NHS restores phagocytic capacity. These findings argue against the presence of an inhibitor of phagocytosis in complement deficient sera. No significant correlation was found between the phagocytosis 

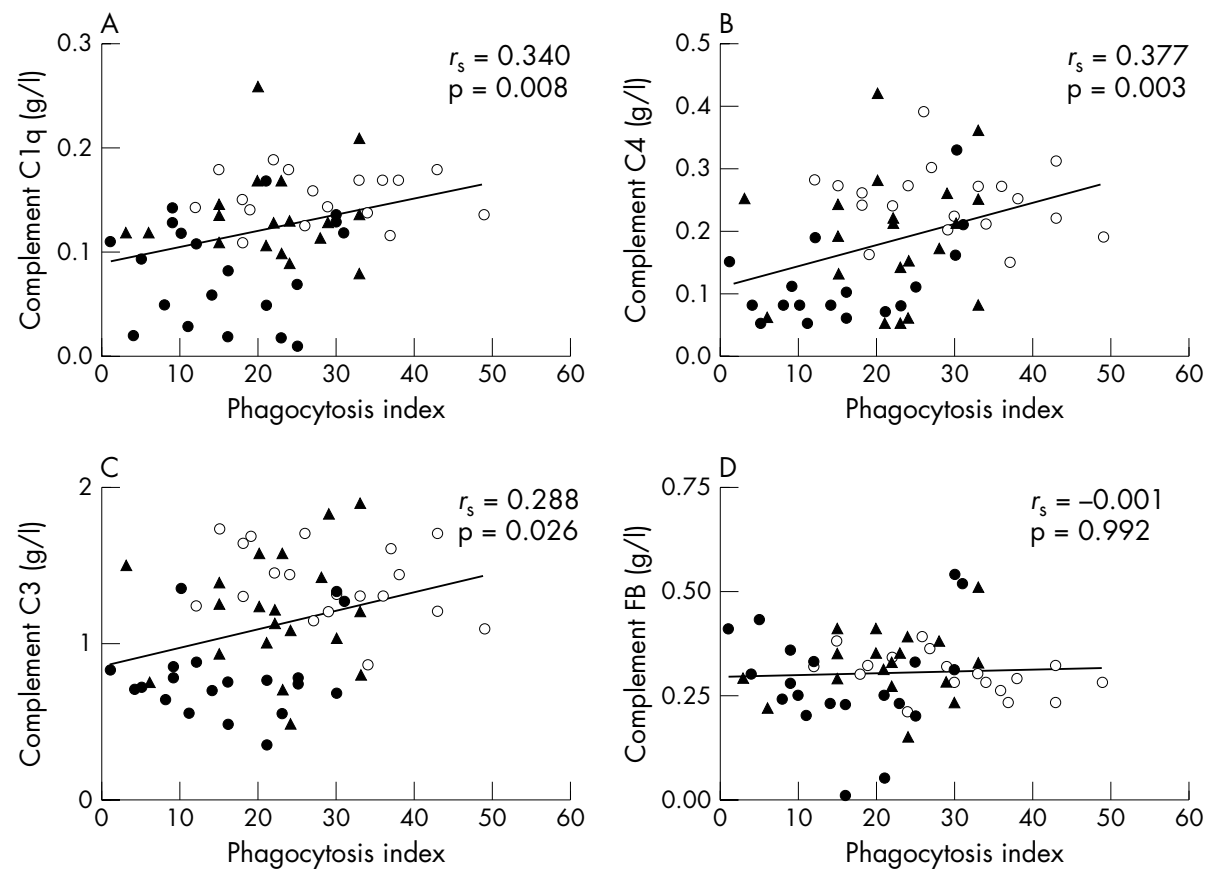

Figure 4 Correlation between levels of complement components $\mathrm{Clq}(\mathrm{A}), \mathrm{C} 4(\mathrm{~B}), \mathrm{C} 3(\mathrm{C})$, factor $\mathrm{B}(\mathrm{D})$ and the phagocytosis index. MDM from healthy controls were incubated with apoptotic Jurkat cells in the presence of $30 \%$ serum derived from healthy controls ( $n=20$, open circles) or patients with SLE $(n=20)$. Paired samples were used obtained during active disease (filled circles) and during inactive disease (filled triangles). Correlation was calculated using data from all experiments $(n=60)$.

index and levels of complement factor B. In the system used we were unable to analyse the specific influence of the separate complement factors independently of each other. The defect in clearance of apoptotic cells in vivo as demonstrated by others might be explained by the (relative) deficiency of complement $\mathrm{Clq}$ and $\mathrm{C}^{4} .^{41}$ It should be mentioned that other serum proteins also play a part in the uptake of apoptotic cells. Serum contains many other constituents, such as the pentraxins CRP, serum amyloid $P$ and pentraxin-3, phospholipase A2, surfactant, all of which influence the capacity to internalise apoptotic cells. ${ }^{17} 21{ }^{42-45}$ In addition, the spectrum of autoantibodies present in the serum of patients with lupus might influence the uptake of apoptotic cells. In this respect, it should be noted that autoantibodies, when they opsonise apoptotic cells, seem to facilitate the internalisation of these cells through different receptors. ${ }^{46}$ The absence of a relation between CRP levels, levels of antibodies to dsDNA, or the presence of antiphospholipid antibodies and the phagocytosis index argues against a strong inhibitory influence of these serum factors in the uptake of apoptotic cells in patients with SLE.

In conclusion, we confirm that phagocytosis of apoptotic cells in patients with SLE is reduced. This is, however, not because of an intrinsic defect of MDM from patients with SLE but is associated with serum factors involved in the opsonisation of apoptotic cells. The association we found between phagocytic capacity of apoptotic cells and serum complement levels of Clq, C4, and (to a minor extend) C3, as found in this study, suggests that the previously reported phagocytic defects in patients with lupus are the result of decreased complement levels which are commonly seen in this disease.

\section{ACKNOWLEDGEMENTS}

This study was supported by grant 00-23 from the Jan Kornelis De Cock-Stichting.

\section{Authors' affiliations}

M Bijl, E Reefman, C G M Kallenberg, Department of Internal Medicine, Division of Clinical Immunology, University Hospital, Groningen, The Netherlands

G Horst, P C Limburg, Department of Pathology and Laboratory Medicine, University Hospital, Groningen, The Netherlands

\section{REFERENCES}

1 Tax WJ, Kramers C, van Bruggen MC, Berden JH. Apoptosis, nucleosomes, and nephritis in systemic lupus erythematosus. Kidney Int 1995;48:666-73.

2 Taylor PR, Carugati A, Fadok VA, Cook HT, Andrews M, Carroll MC, et al. A hierarchical role for classical pathway complement proteins in the clearance of apoptotic cells in vivo. J Exp Med 2000;192:359-66.

3 Botto M, Dell'Agnola C, Bygrave AE, Thompson EM, Cook HT, Petry F, et al. Homozygous Clq deficiency causes glomerulonephritis associated with multiple apoptotic bodies. Nat Genet 1998;19:56-9.

4 Mitchell DA, Taylor PR, Cook HT, Moss J, Bygrave AE, Walport MJ, et al. Cutting edge: Clq protects against the development of glomerulonephritis independently of C3 activation. J Immunol 1999;162:5676-9.

5 Korb LC, Ahearn JM. Clq binds directly and specifically to surface blebs of apoptotic human keratinocytes: complement deficiency and systemic lupus erythematosus revisited. J Immunol 1997;158:4525-8.

6 Nauta AJ, Trouw LA, Daha MR, Tijsma O, Nieuwland R, Schwaeble WJ, et al. Direct binding of $\mathrm{Cl} q$ to apoptotic cells and cell blebs induces complement activation. Eur J Immunol 2002;32:1726-36.

7 Walport MJ. Complement. Second of two parts. N Engl J Med 2001;344:1140-4.

8 Herrmann M, Voll RE, Zoller OM, Hagenhofer M, Ponner BB, Kalden JR. Impaired phagocytosis of apoptotic cell material by monocyte-derived macrophages from patients with systemic lupus erythematosus. Arthritis Rheum 1998;41:1241-50.

9 Aderem A, Underhill DM. Mechanisms of phagocytosis in macrophages. Annu Rev Immunol 1999; 17:593-623.

10 Fadok VA, Bratton DL, Rose DM, Pearson A, Ezekewitz RA, Henson PM. A receptor for phosphatidylserine-specific clearance of apoptotic cells. Nature 2000:405:85-90.

11 Scott RS, McMahon EJ, Pop SM, Reap EA, Caricchio R, Cohen PL, et al. Phagocytosis and clearance of apoptotic cells is mediated by MER. Nature 2001;411:207-11.

12 Savill J, Dransfield I, Hogg N, Haslett C. Vitronectin receptor-mediated phagocytosis of cells undergoing apoptosis. Nature 1990;343:170-3.

13 Hack CE, Wolbink GJ, Schalkwijk C, Speijer H, Hermens WT, van den BH. A role for secretory phospholipase A2 and C-reactive protein in the removal of injured cells. Immunol Today 1997;18:111-15. 
14 Mevorach D, Mascarenhas JO, Gershov D, Elkon KB. Complement-dependent clearance of apoptotic cells by human macrophages. J Exp Med 1998;188:2313-20.

15 Gershov D, Kim S, Brot N, Elkon KB. C-Reactive Protein binds to apoptotic cells, protects the cells from assembly of the terminal complement components, and sustains an antiinflammatory innate immune response. Implications for systemic autoimmunity. J Exp Med 2000;192:1353-64.

16 Bickerstaff MC, Botto M, Hutchinson WL, Herbert J, Tennent GA, Bybee A, et al. Serum amyloid $\mathrm{P}$ component controls chromatin degradation and prevents antinuclear autoimmunity. Nat Med 1999;5:694-7.

17 Rovere P, Peri G, Fazzini F, Bottazzi B, Doni A, Bondanza A, et al. The long pentraxin PTX3 binds to apoptotic cells and regulates their clearance by antigen-presenting dendritic cells. Blood 2000;96:4300-6.

18 Tan EM, Cohen AS, Fries JF, Masi AT, McShane DJ, Rothfield NF, et al. The 1982 revised criteria for the classification of systemic lupus erythematosus. Arthritis Rheum 1982;25:1271-7.

19 ter Borg EJ, Horst G, Hummel EJ, Limburg PC, Kallenberg CG. Measurement of increases in anti-double-stranded DNA antibody levels as a predictor of disease exacerbation in systemic lupus erythematosus. A long-term, prospective study. Arthritis Rheum 1990;33:634-43.

20 Bombardier C, Gladman DD, Urowitz MB, Caron D, Chang CH. Derivation of the SLEDAl. A disease activity index for lupus patients. The Committee on Prognosis Studies in SLE. Arthritis Rheum 1992;35:630-40.

21 Bijl M, Horst G, Bijzet J, Bootsma H, Limburg PC, Kallenberg CG. Serum amyloid $\mathrm{P}$ component binds to late apoptotic cells and mediates their uptake by monocyte-derived macrophages. Arthritis Rheum 2003;48:248-54.

22 Ren Y, Tang J, Mok MY, Chan AW, Wu A, Lau CS. Increased apoptotic neutrophils and macrophages and impaired macrophage phagocytic clearance of apoptotic neutrophils in systemic lupus erythematosus. Arthritis Rheum 2003;48:2888-97.

23 Herrmann M, Voll RE, Kalden JR. Etiopathogenesis of systemic lupus erythematosus. Immunol Today 2000;21:424-6.

24 Maekawa Y, Yasutomo K. Defective clearance of nucleosomes and systemic lupus erythematosus. Trends Immunol 2001;22:662-3.

25 Casciola-Rosen LA, Anhalt G, Rosen A. Autoantigens targeted in systemic lupus erythematosus are clustered in two populations of surface structures on apoptotic keratinocytes. J Exp Med 1994;179:1317-30.

26 Utz PJ, Hottelet M, Schur PH, Anderson P. Proteins phosphorylated during . stress-induced apoptosis are common targets for autoantibody production in patients with systemic lupus erythematosus. J Exp Med 1997; 185:843-54.

27 Utz PJ, Anderson P. Posttranslational protein modifications, apoptosis, and the bypass of tolerance to autoantigens. Arthritis Rheum 1998;41:1152-60.

28 Mevorach D, Zhou JL, Song X, Elkon KB. Systemic exposure to irradiated apoptotic cells induces autoantibody production. J Exp Med 1998; 188:387-92.

29 Patry YC, Trewick DC, Gregoire M, Audrain MA, Moreau AM, Muller JY, et al. Rats injected with syngenic rat apoptotic neutrophils develop antineutrophil cytoplasmic antibodies. J Am Soc Nephrol 2001;12:1764-8.

30 Cairns AP, Crockard AD, McConnell JR, Courney PA, Bell AL. Reduced expression of CD44 on monocytes and neutrophils in systemic lupus erythematosus: relations with apoptotic neutrophils and disease activity. Ann Rheum Dis $2001 ; 60: 950-5$.
31 Steinbach F, Henke F, Krause B, Thiele B, Burmester GR, Hiepe F. Monocytes from systemic lupus erythematous patients are severely altered in phenotype and lineage flexibility. Ann Rheum Dis 2000;59:283-8.

32 Licht R, Dieker JW, Jacobs CW, Tax WJ, Berden JH. Decreased phagocytosis of apoptotic cells in diseased SLE mice. J Autoimmun 2004;22:139-45.

33 Licht R, Jacobs CW, Tax WJ, Berden JH. No constitutive defect in phagocytosis of apoptotic cells by resident peritoneal macrophages from pre-morbid lupus mice. Lupus 2001;10:102-7.

34 Potter PK, Cortes-Hernandez J, Quartier P, Botto M, Walport MJ. Lupus-prone mice have an abnormal response to thioglycolate and an impaired clearance of apoptotic cells. J Immunol 2003;170:3223-32.

35 Erwig LP, Gordon S, Walsh GM, Rees AJ. Previous uptake of apoptotic neutrophils or ligation of integrin receptors downmodulates the ability of macrophages to ingest apoptotic neutrophils. Blood 1999;93:1406-12.

36 Courtney PA, Crockard AD, Williamson K, Irvine AE, Kennedy RJ, Bell AL. Increased apoptotic peripheral blood neutrophils in systemic lupus erythematosus: relations with disease activity, antibodies to double stranded DNA, and neutropenia. Ann Rheum Dis 1999;58:309-14.

37 Shoshan Y, Shapira I, Toubi E, Frolkis I, Yaron M, Mevorach D. Accelerated Fas-mediated apoptosis of monocytes and maturing macrophages from patients with systemic lupus erythematosus: relevance to in vitro impairment of interaction with iC3b-opsonized apoptotic cells. J Immunol 2001;167:5963-9.

38 Chen Z, Koralov SB, Kelsoe G. Complement C4 inhibits systemic autoimmunity through a mechanism independent of complement receptors CR1 and CR2. J Exp Med 2000;192:1339-52.

39 Einav S, Pozdnyakova OO, Ma M, Carroll MC. Complement C4 is protective for lupus disease independent of C3. J Immunol 2002; 168:1036-41.

40 Grevink ME, Horst G, Limburg PC, Kallenberg CG, Biil M. Levels of complement in sera from inactive SLE patients, although decreased, do not influence in vitro uptake of apoptotic cells. J Autoimmunity 2005;24:329-36.

41 Baumann I, Kolowos W, Voll RE, Manger B, Gaipl U, Neuhuber WL et al. Impaired uptake of apoptotic cells into tingible body macrophages in germinal centers of patients with systemic lupus erythematosus. Arthritis Rheum 2002;46:191-201.

42 Leverrier Y, Lorenzi R, Blundell MP, Brickell P, Kinnon C, Ridley AJ, et al. Cutting edge: the Wiskott-Aldrich syndrome protein is required for efficient phagocytosis of apoptotic cells. J Immunol 2001;166:4831-4.

43 Mold C, Gresham HD, Du Clos TW. Serum amyloid P component and Creactive protein mediate phagocytosis through murine Fc gamma Rs. $\mathrm{J}$ Immunol 2001;166:1200-5.

44 Ogden CA, deCathelineau A, Hoffmann PR, Bratton D, Ghebrehiwet B, Fadok VA, et al. Clq and mannose binding lectin engagement of cell surface calreticulin and CD91 initiates macropinocytosis and uptake of apoptotic cells. J Exp Med 2001;194:781-95.

45 Schagat TL, Wofford JA, Wright JR. Surfactant protein A enhances alveolar macrophage phagocytosis of apoptotic neutrophils. J Immunol $2001 ; 166: 2727-33$

46 Manfredi AA, Rovere P, Galati G, Heltai S, Bozzolo E, Soldini L, et al. Apoptotic cell clearance in systemic lupus erythematosus. I. Opsonization by antiphospholipid antibodies. Arthritis Rheum 1998;41:205-14. 